\title{
An Evaluation of the National English Language Exam in Jordan for Postgraduate Studies: Validity and Reliability
}

\author{
Mr. Firas Ali Obeidat \\ Ph.D. Candidate, Corner of Richmond and Marianhill Road, Edgwood Campus, \\ University of KwaZulu-Natal, South Africa, Private Bag X03. Ashwood, 3605
}

Professor Ayub Sheik

Professor of English Education, Corner of Richmond and Marianhill Road, Edgwood

Campus, University of KwaZulu-Natal, South Africa, Private Bag X03. Ashwood, 3605

Received: March 16, 2021 Accepted: August 10, 2021 Published: August 13, 2021

doi:10.5296/ijele.v9i2.18936 URL: https://doi.org/10.5296/ijele.v9i2.18936

\begin{abstract}
This paper aims to evaluate the validity and reliability of the National English Language Exam (NELE) in Jordan for postgraduate studies. According to reviewing the most related studies using the review method, it was found that the NELE is valid and reliable depending on the evaluation of the Commission for Accreditation and Quality Assurance (CAQA) in Jordan. However, it was indicated that no studies discussed the validity and reliability of the NELE in Jordan. Otherwise, few studies evaluated the English language courses like Action Pack and Petra used by the Ministry of Education in Jordan to teach English as a foreign language. These studies found that these courses are valid and reliable. As well as, it was concluded that an enormous shortage in the literature that discussed the validity and reliability of the NELE in more depth and details. Therefore, this paper recommends more studies to evaluation the reliability and validity of the NELE in Jordan.
\end{abstract}

Keywords: NELE, validity, reliability, evaluation, postgraduate, CAQA 


\section{Introduction}

Through increasing demands on professional people to work and make significant changes in the work environment, higher education becomes one of the most important job requirements in international work and jobs. Many people realized this fact and started preparing to continue their education, to specialize in specific areas, develop in their job descriptions, and improve the quality of their life. The main aim of the universities' learning is to supply the students with comprehensive operations included in their specialty field and prepares them for professional jobs in the fields where they are interested (Sharabati and Zamil 2015)

In Jordan, graduate students must first take the National English Language Exam (NELE) before starting the postgraduate studies. For that reason, the specialist, who must write the questions of this exam, should take into consideration the validity and reliability of this exam. So, they should assure that this exam evaluates and measures effectively English proficiency among graduate students. Knowing that these students would study any specialization subject in the English language at the university, thus it is significant to have a high skill in the English language. But this type of exam is not limited in Jordan, all the graduate students from all the world should take similar exams, which is known as TOEFL, IELTS, GMAT, LSAT GRE, or other national or international exams to study inside or outside their countries (Alkhawaldeh 2017).

\subsection{Importance of the Problem}

Learning English has been the most difficult subject so far, and many students cannot learn it as a foreign language in easy ways. Although learning English started from the primary level in the Jordanian school, it is still a hard task for realizing. Many researchers studied the challenges and difficulties that faced students and teachers in the Arab world in general, and in Jordan in specific (Alzayyat 2014; Abu-Irmies 2014; Bani-Khaled 2013; Rabab'ah 2003). However, this study is considered the first review study that sheds light on the extent to which NETE reflects test-takers' English proficiency in Jordan.

Generally, various studies identified English as a Foreign Language test to evaluate student's proficiency in the English language in the Arab world, and especially in Jordan. For example, Hashisho (2009) found that the situation of instruction teaching for the English language among the teachers of the Jordanian public schools was at a low level. Moreover, he stated that many students have a low-level of English communication and proficiency.

\subsection{Background}

In Jordan, each graduate student must pass the TOFEL exam or NELE for postgraduate studies admission. This rule was set by the Higher Education Council on May 29, 2015, for the 7 th session. It stated that if a graduate student fails three times and gets above $40 \%$ grade in the NELE, they can take an English course before starting their postgraduate studies. This course is equivalent to three credit hours. However, if the student fails three times and gets below $40 \%$ grade in the NELE, the student can record in two English courses, which equivalent to six credit hours. In all these cases, graduate students must retest the NELE or equivalence to get the pass mark before they start their postgraduate studies (Alkhawaldeh 2017). 
The main aim of these English courses is to prepare graduate students to cope and connect effectively in the English language. The Educational Testing Service (2008) indicated that all the graduate students need the English language in conducting different tasks successfully in their postgraduate study, such as writing papers, explaining their opinions, generating and creating the hypothesis, and other communication skills.

\subsection{Purpose}

This study aims to evaluate the NELE in Jordan for postgraduate studies. Thus, the following questions of this paper formulated to achieve the paper goals:

1. Is the NELE in Jordan for postgraduate studies valid?

2. Is the national NELE in Jordan for postgraduate studies reliable?

3. What are the steps that have been followed up to evaluate the NELE in Jordan efficiently?

To answer these questions, the researcher will review the related studies, discuss in what way these studies evaluate the NELE.

\section{Literature Review}

\subsection{Higher Education in Jordan}

Higher education in Jordan is widely developed in recent years by increasing the number of courses, students, faculties, and the academic and administrative staff. Despite the lack of financial resources, large money was spent in this sector in Jordan due to its significance in enhancing the economic, knowledge, and social awareness level among the Jordanian (The Education, Audiovisual and Culture Executive Agency, (EACEA) 2017).

The higher education sector in Jordan became independent in its economic, financial, and administrative matters, which give this sector a massive space to rebuild and reshape the Ministry of Higher Education in Jordan. As in 2009, the new law of the government issued for the higher education system whether private or public universities, which are the Jordanian universities law No. 20 and law of higher education No. 23. The new structure includes two units (MOHE 2009; MOHE 2009a; Arabian Business Consultants for Development, (ABCD) 2007):

1. Policy Analysis and Planning Unit: it is responsible for gathering information and data about the higher education sector, conducting the researches that support the council of the higher education operations, and several other roles issued in this law.

2. Unified Admission Coordination Unit: it is responsible for admission of the students in the public universities to the main approved by the council of higher education.

The council of higher education for all universities issued the admission policy and standards for master postgraduates' studies, which are as follow (EACEA 2017):

1. At least, the students have a good grade in the bachelor's degree.

2. Having proficiency in the English language, by getting a certain score in an international English exam (IELTS/ TOEFL), or NELE. 


\subsection{The national English exam in Jordan}

The NELE is considered as a high-stake exam in Jordan. Therefore, it is a focal point in a person's life, which determines whether the student is capable and has a chance to continue his/her postgraduate studies or not. According to the Glossary of Education Reform:

A high-stakes test is any test used to make important decisions about students, educators, schools, or districts, most commonly for the purpose of accountability-i.e., the attempt by federal, state, or local government agencies and school administrators to ensure that students are enrolled in effective schools and being taught by effective teachers. In general, "high stakes" means that test scores are used to determine punishments (such as sanctions, penalties, funding reductions, negative publicity), accolades (awards, public celebration, positive publicity), advancement (grade promotion or graduation for students), or compensation (salary increases or bonuses for administrators and teachers) (2014, para 1).

This type of exam gives participants several benefits and improves the quality of their life if they pass it (Embse and Hasson 2012).

\subsection{English Language Proficiency}

Stephen, Welman, and Jordaan (2004), defined that language proficiency is a measured way to test the person's capability to employ the learned language in communication skills. Davies (1997) explained that language proficiency as a test method used to know the level of the students or learners in a foreign language. However, Llurda (2000) determined language proficiency is a kind of transforming the process of learned skills into actions that may be needed in life by using this learned language. As well, Hughes (2003) stated that the proficiency language test should not take into consideration the training and objectives in the syllabus of any English learned course and its training activities in designing and creating the proficiency exam content. Coombe, Folse, and Hubly (2007) indicated that the proficiency exam should evaluate the learner's ability to use the English language in the total exam and in what extent the learners developed in the learn this language, but should not design it based on the needs of specific curriculum or program.

Bekdaş (2015) defined English language proficiency as the acquisition of the skills in using the English language. Multiple exams conduct to test the abilities of students or learners in employing the productive and receptive skills of the English language in the right way throughout the whole exam sections; reading, speaking, vocabulary, writing, listening skills.

According to Bekdaş (2015), the language proficiency is divided into three-levels, which the following level changes gradually with the increasing of the person's ability to use the English language in a good context with clearly content in right function, and good accuracy, the levels are as follow:

- Function: referred to test the person's ability to finish a linguistical task clearly, such as a good description and asking the right questions.

- Context/content: referred to test the good shaping and design of the text.

- Accuracy: referred to test the level of validity and clarity of the message that wants to reach for the listener and reader. 
Graduate learning is a complex process and based mainly on individual capability more than the teaching ways and tools or teachers. The reason for that is the graduate students have different levels and large experience of life. Thus, the graduate students have a change in perceptions, opinions, and it is expected that they have cognitive priorities that differ from the undergraduate. English language skill is one of the basic skills that graduate students must have high-level English because it is an international language, which they need in their every life aspect (Hardré and Hackett 2015).

Furthermore, Martirosyan, Hwang, and Wanjohi (2015) pointed out that the students from non-English speaking countries faced many difficulties and problems in communicating in English language, speaking skills, understanding of the words, having bad writing skills and paragraphing in English, as well. All these skills measure the level of English proficiency among the students that point out to the student's success or failure in their academic process.

Otherwise, educational language efficiency level and performance can be affected by many elements and factors. A lot of factors that play an essential role in the educational performance of students. For example, in some countries, the funds to learn English are extremely high and most people cannot afford them. According to analysts, the most important elements which play a vital part in the English Language performance of students are social factors and the economy (El-Omari 2016; Salameh 2012).

\subsection{Factors Affecting the Performance of the English Language}

Down below will have details about the economic and social factors, which can affect the performance of the English language. It is essential to talk about these factors, firstly by explaining some models and theories, and then analyzing the connection between these elements and the performance of the English Language.

The first factor is economics, which is one of the main factors that make almost every part of our life. Rich people can get more opportunities to learn, communicate, travel, and register into several courses to improve their skills and increase their knowledge of a specific topic. Real-life examples of this exist in the current economic environment in which people who have a strong economic background take-over the entire society. Many authors and researchers pointed out that economic factors are the most significant for a person or an economy (Salameh 2012).

The second factor is social factors which are very significant to be affected and influenced accordingly as well. Social Factors include behavioral factors that have a real effect on someone's life. Family and school are the two main social circumferences in which a child emerges, so there is a regularity between the learner and his/her circumference. The social portions of language conquest culminate in the differences in language improvement and use between the learners from different social classes (El-Omari 2016).

Additionally, Snell (2014) said that the basic assumption about learning language was heard and spoken by a child from a lowest-class home, which has different content from the language used by a child from a middle-class home background. The social influence of middle-class children at home helps them improve more vocabulary, while working-class 
children, who do not get this chance for learning, have face difficulty in the formal conditions.

The biggest part that plays a significant role in affecting the performance of English language learners is mental contentment. Economic growth will frequently promote the performance level of a student towards learning to get a high level in the English language. But the situation is not always right, because sometimes the growth of the economy makes a person rude and arrogant. Previous studies mentioned many times Maslow's theory, which indicated that mental contentment has a strong connection with the economic situation of a person.

\subsection{The Challenges of the Preparation Process for Learners to the English Test Exam}

After briefly reviewing the important factors that have significant effects on the development of learning English, it is worth talking about the challenges of the preparation process of the English language test (TOFEL, IELTS, or even NELE) from the teacher's point of view. Six main challenges will be discussed in the next paragraphs:

Firstly, learners' high expectations from the information given by the teachers. Most of them agree that the students' high anticipations are one of the main problems they managed over their teaching experience. Most of the students have a deficiency of understanding the English language, however, students anticipate getting a high degree in the NELE, which leads teachers to became tiring to teach their students this language. It means that the students should have a basic understanding of English before they begin to study the test preparation (Roza 2019).

Other comments also came from teachers, who said that the students come with high expectations, while their results are very low. For example, in TOEFL, the students get below 400 but anticipate getting a result of 500 or 550. This anticipation burdens them very much because it is hard to fulfill since it takes a long time and hard work (Al-Rawashdeh 2010).

The second challenge is students' lack of effort. Most students with high expectations do not make enough effort. The high school pupils do not have the incentive for studying, while the adults tended to be serious about it (Erfani 2014).

Moreover, some students don't make an effort in the test preparations because of their parents who forced them to study. Usually, parents want their children to study in school or to have better jobs, but children do not interest in doing one of those. Thus, these forced students do not pay attention and do not make enough effort to get a good result. All in all, the teachers who are responsible for the students face a tough challenge for both the parents and students (Roza 2019).

Thirdly, the limited preparation time for the test is considered one of the problems in the test preparation as well. Most students decide to begin preparations for the English language test at the last minute. Thus, students cannot start studying slightly before the start date of the test, especially when they have a high score to reach (Roza and Kunci 2019).

Fourthly, the next challenge is the teacher's experience of teaching TOEFL, IELTS, and NELE. A lot of teachers agreed that they still have tension and lack of confidence while teaching TOEFL, IELTS, and NELE, even though they have been teaching for more than two 
years and have qualifications to teach. The reason is the students get smarter, while the teachers still use the books to guide them through their teaching process. Therefore, they need to update their knowledge, so they could overcome their anxiety during the teaching process (Ball and Forzani 2009). Teachers needed to update themselves with new vocabulary and test forms, so they would not be left behind with the trend and would be more advanced than the students. Based on the experience, smarter students tended to underestimate their teachers and will not be motivated to study anymore (Ball and Forzani 2009)

Fifthly, most of the teachers complain that high school students are noisy, not compliant, and always confused by their mobile phones. On the other hand, other teachers agreed that high school students are disciplined, and they obey the rules and schedule. They said that adults tended to make more excuses and be undisciplined (Roza 2019).

The final challenge is the number of students in the class. If one class has many students, there are no benefits to learn the TOEFL, IELTS, or NELE materials. From the teacher's point of view, many students in the same class make a very poor learning environment. As well as, they could not control the students, which made the situation worse, especially when students have a poor English language background that makes the learning process with spiritless (Herreid 2006).

Besides, they indicated that it is more efficient for them to teach a smaller group consisting of few students than many students because it could motivate them to study in more focus the English language, to become ready for the English preparation exam. Moreover, the benefits of having fewer students in the class make effective progress in learning English for the test English preparations to get the targeted score (Herreid 2006).

\subsection{The Objective of the NELE}

The main aims of the NELE are to indicate the level of graduate students in the English language, which referred to an academic learner tool to test their skills in the English language and get content understanding in academic topics and material (Taguchi 2014).

Furthermore, the Ministry of Higher Education and Scientific Research (MHSR) created a national English Language test to measure the English language competencies for the Jordanian graduate students, who plan to continue the postgraduate studies in the Jordanian universities. This exam includes five sections, each section tests the competency of the students in this section related to the English language skills with a total of 100 marks, which are (MHSR, 2019):

1. The listening comprehension part has 20 questions with 20 marks.

2. The reading comprehension part separated into four passages has 20 questions with 20 marks.

3. The structure part has 20 questions with 25 marks.

4. The written expressions part has 20 questions with 20 marks.

5. The vocabulary part has 15 questions with 15 marks.

Every part measures several skills related to the English language proficiency for the students: 
Firstly, listening comprehension is the listening process, includes hearing oral speech and sounds that help the listeners to understand the oral dialogue by classifying the words into two groups, the syntactic and lexical units to understand these dialogues, which measures the following skills, classified into (Orbe 2019):

* Understanding the speech sounds of each word to speak English fluently,

* Understanding the concepts for every word to employ this word in English conversation they participate,

* Comprehending the syntax of the words to use it in English conversation they participate,

* Helping in conducting and communicating in daily tasks fluently,

* Helping to understand and respond to the questions in speaking English conversations they participate fluently.

The second part is reading comprehension, which focuses on the reading comprehension that needs to understand what you are reading and realizing the aims of the reading process (Kirby 2007). This part includes many skills that determine the level of the students in reading English context, which is (Dwiniasih and Nugraha 2019):

* Understanding the general idea of the English texts,

* Realizing the organizing coherently of the English texts,

* Understanding the general meaning of the English texts,

* Helping to know a wide range of the word definitions and how can they effectively use it in the English text.

Thirdly, the structure section includes speaking skills that measure the competency of the speaking process include the speech to the other in the English language expressing themselves and communicate with others. This section tests the ability of the student in the following skills that relate to the speaking (Al-Eiadeh et al. 2016):

* Knowing how to choose an excellent subject,

* Organizing their opinion,

* Abilities to connect their ideas and communicate with others,

* Reacting with the listener's feedback effectively,

* Expressing themselves and their ideas with excellent word choice.

Fourth, writing expression is the process of express the opinion of a person to write it in the specific structure and frame. This section includes various skills that test the abilities of the students in writing expression using the English language, which are (Can 2017):

* Easy creating texts,

* Competency of the grammar rules, punctuation, and spelling,

* The excellent readability of the writing text,

* Organize their ideas, and connect it in the right way,

* Their texts are clear and understandable,

* Choose wisely the subjects and the way that presents it.

Finally, the vocabulary section includes the meaning of the new words, to measure the 
number of words that students know in the English language. If students know and understand a wide range of the word meaning, it will help them to wisely use it, whether in speaking, writing, or even reading process. It helps students in communicating effectively with others and increases their self-confidence because they can easily understand, read, respond with the exact word, and they can avoid many problems in learning or communicate with the English language (Susanto 2017).

Otherwise, Ertürk (2015) stated that when the specialist develops any exam to measure the skills that learners have, it must test the following items to approve the exam's efficiency; quality, clarity of the instructions, reliability, validity, layout, arrangement, and design. Weir (2005) stated that to test the competency in such skills, including reading, writing, speaking, and vocabulary, an appropriate test tool must be chosen to give the scores and be a real reflection of the participant's capabilities. The test chosen must be examined to assure its validity and reliability. But first, it must understand the best design and shape of the exam, to effectively choose the method to test its validity.

Moreover, IELTS Handbook (2007) indicated that testing the validity or reliability for the English language competency exam can be achieved by gathering all related data about this exam. It can get a real score for this exam. Besides, the test process includes the ethical factors, which referred to coherent validity as well.

Moreover, Shohamy, Lair, and May (2007) identified the meaning of the validity test of the English exam as to measure the skills of something, and this measure is giving the exact or actual ability and knowledge of these skills. While, the reliability test of the English exam is the matchmaking of the exam scores with the factors and items that want to measure, which means that if the learners repeat the exam several times they will get the same results.

\section{Methodology}

This paper discussed the evaluation of the NELE in Jordan for postgraduate studies into the validity and reliability issue of this exam. To achieve this objective, this paper will review the most related studies on this issue.

Thus, this paper decided to adopt the review research method, which focuses on database and information about a specific matter, to achieve the paper goals through analyzing the collected data and information on the specific matter. These databases and information previously indicated by the researchers could be articles, journals, studies, research, and others (Martins, Cunha and Serra 2018). These types of previous studies followed a specific method and discussed several results about the paper's matter that will be discussed in this paper.

This paper will collect, analyze and review the results of the previous reliable and valid studies, such as governmental agency, academic articles, researches, and reports recently published from 2015 to 2020 that discuss the NELE and its evaluations in terms of validity and reliability in Jordan. It will review the other similar exam in other countries to recommend the steps of the evaluation process of this exam effectively. 
Alkhawaldeh (2017), analyzed the validity and reliability of the National English courses as an alternative way to develop the graduate student's capability of English language skills in the universities of Jordan. He used a qualitative method to discuss this matter by asking some questions about the matter to twenty-two postgraduate students from several faculties at the University of Jordan. He found that the national English language courses will help them to develop their skills in the English language, through increasing their new vocabulary, grammatical rules, and making them more proficient in their reading and writing skills. Thus, the national English language courses are valid and reliable in developing English language skills for postgraduate students from several faculties at the universities of Jordan.

International Labour Organization (ILO), (2015), studied the minimum needs for tested skills and certification producers in Jordan. These evaluation producers analyzed the following four matters:

i. First, it should describe briefly the evaluation and tests process in Jordan.

ii. Second, the principles of the evaluation and labor tests, should:

a. Fit the total competency in the concentration of the knowledge with the tested skills.

b. Be the same with the competency-based on the same approach or equivalent, but the evaluation process of the test may be different.

c. Encourage the specialist to participate in the design, conducting, and reviewing the tests.

d. Determine the specific standards of test circumstances to make it reliable.

iii. Third, it should understand the prior teaching of the skills that must be tested, depending on the resources of funding for several levels, because the testing and certification are expensive costs.

iv. Fourth, it should take into consideration the guidance for the methods to create skills tests

The following seven steps that generated to formulate and design every skill's test in an effective way:

- The first step, setting up the tasks and goals for the test,

- The second, arranging a test characteristics table,

- The third, building approaches for a skill test,

- The fourth, selecting the excellent evaluation way for the practical skill's test,

- The fifth, creating an evidence model,

- The sixth, choosing evaluation tools for the empirical skills test,

- The final step, achieving the conceptual test and the evaluation tools.

Five steps formulated to effectively conduct every skill's test to assure the main guidelines for conducting the skills tests:

- Preparation for the skills test that wants to conduct,

- Doing the skills test, recording and documenting the outcomes,

- Arranging the appeal and redoing the process,

- Awarding the certification, 
- Test process improvements.

Most of the evaluation tools and skills tests include five evaluation tools, direct/indirect evaluation producers, project evaluation ways, simulation evaluation producers, interview and question-based evaluation procedures, and performance portfolio evaluation ways, categorized into four labor level in Jordan according to ILO (2015):

Firstly, the technician level is a high level in scientific, supervision, and technical skills.

Secondary, the craftsman level is a high level of technical skills.

Thirdly, the skilled level is a competency level in the specific occupational area.

And finally, a limited-skilled level is the capability to achieve routine works and tasks.

All the designing and creating skill tests' procedures should be conducted in close corporation between the specialists and the CAQA (Commission for Accreditation and Quality Assurance). In this way, the skill tests can be approved to be a valid and reliable test in Jordan (ILO 2015).

On the other hand, Bani-Khaled (2013) indicated that there is an insufficient number of studies that prove the reliability and validity of the National English exam for postgraduate studies in Jordan.

Otherwise, Latitude Aviation English Services, (LAES) (2017) examined whether the checkpoint is valid and reliable to measure the English language skills or not. A total of 1,200 participants of post-graduate students at Lancaster University conducted the checkpoint exam. This checkpoint exam was measured by using the following tools: standard error of the measurements, item discrimination, Cronbach alpha reliability results, and the relationship of the listening, speaking and reading tests.

These tools used to test the content and the scope of the exam, the relationship between the aviation training and the language used (English language), the participant's characteristics, the relation between the linguistic knowledge and subject, and the checkpoint test management. It found that the checkpoint exam developed to meet the language measuring needs. In other words, checkpoints are valid and reliable to measure the English language skills for post-graduate students at Lancaster University (LAES 2017).

Moreover, Sugianto (2016) analyzed the validity and reliability of the English National Final exam for Junior high school in Indonesia. It used a descriptive method using two tools by content and construct validity, by comparing the content and indicators of the syllabus to the factors of the test, and KR20 referer to Kunder-Richardson Formula, to test the reliability. It pointed out that the national final English language exam for Junior high school in Indonesia is $100 \%$ valid and reliable to such a great extent, the total properties of the exam classified as an excellent exam.

Sims (2015), provided effective steps to formulate and design high reliability and an appropriate validity for the competency English language exam, with a relationship to test of TOEFL exam in Taiwan university. It developed six processes to test the efficiency of the language exam, as follow: 
1. Set the aim of the test,

2. Formulate the test properties,

3. Select the test factors,

4. Evaluate the test context,

5. Point out the scores of the registration process,

6. Achieve the validity test for the context, framework, and agreed and reliability tests include Cronbach's alpha and split-half test.

This study concluded several effective changes in the TOEFL to be a valid and reliable exam and can measure the student's ability in the English language.

Moreover, Akmar, Abidin, and Asiah (2015) developed a new way and method to evaluate the validity of the English proficiency exam for postgraduates in Malaysia. This study designed a model to test the process created by Akmar, Abidin, and Asiah (2015). This process based on two main issues; which are the test development process and test levels, learning and teaching language to measure the validity and reliability of the English competency exam. It showed no relation between the student's ability and the real performance within the exam in Malaysia. Thus, this exam includes most of the descriptions and planning of the test, which contains the multi-valid factors to evaluate the exam based on the framework of the exam validation designed by Weir (2005).

\section{Findings and Analysis}

According to the first question: is the National English Language Exam (NELE) in Jordan for postgraduate studies valid?

After reviewing previous studies, it was found that the CAQA in Jordan is responsible for assuring the validity of the NELE. As well as, there is an English course conducted in all Jordan universities for those who failed in the NELE, and these types of courses are valid in Jordan.

According to the second question: is the National English Language Exam (NELE) in Jordan for postgraduate studies reliable?

After reviewing the most related studies, it is indicated that the NELE is reliable according to the CAQA in Jordan, which responsible for assuring the reliability of this exam, which should meet goals in testing the English language level among the participants. The qualified commission, who is responsible for measuring their skills level in this language.

According to the third question: what are steps that must follow up to evaluate the NELE in Jordan efficiently?

Regarding the researchers, who conducted the articles and studies that most related to this issue, seven steps were assigned to evaluate the NELE.

The following steps that must be followed to examine the evaluation process are the following:

1- The first step, setting the aims and goals of the English language exam, 


\section{MInstitute ${ }^{\text {Mink }}$}

2- The second step, designing, and developing the English language exam characteristics,

3- The third step, determining the skills that the exam should test,

4- The fourth step, evaluating the English language exam, including its context, exercise, and content, to meet the aims and goals that set for it,

5- The fifth step, getting the score of every skill in the English language exam in the registration process,

6- The sixth step, analyzing the reliability and validity test for the context, framework, and agreed using Cronbach's alpha and split-half test analysis,

7- The final step, conducting interviews with the specialist, who check the participant's answer to this exam, and participants, who take this exam, to ask them about the exam and their feedback about the evaluation of the exam, in terms its validity and reliability. All these steps make to measure the real level of the participants in the English language.

\section{Discussion}

It is found that there are few studies and researches that talked about the evaluation of the English language exam throughout the world in general, and in Jordan in specific (Bani-Khaled 2013).

Most of the studies focused on studying the difficulties that face the graduate students in learning the English language (El-Omari, 2016; Snell 2014; Salameh 2012; Eng 2009), preparation for tests for the English language level test (Roza 2019; Erfani 2014; Al-Rawashdeh 2010; Ball and Forzani 2009), or competency English test (Bekdaş 2015; Martirosyan, Hwang and Wanjohi 2015; Hardré and Hackett 2015).

Moreover, a lot of researches and studies discussed the ways and methods that can motivate the students to effectively prepare to conduct the TOEFL or IELTS or even NELE (Roza 2019; Erfani 2014; Al-Rawashdeh 2010). While there are no direct studies talked about the reliability and validity of the NELE in Jordan for postgraduate studies. But, Alkhawaldeh (2017), indicated that the English language courses took before the NELE, and these courses are valid and reliable.

Moreover, ILO (2015), agreed that every skill exam, such as NELE, is evaluated to assure its validity and reliability in Jordan by the qualified commission. Moreover, the evaluation process that ILO followed to evaluated NELE, is strongly agreed with several researchers, who evaluate the English language exams for postgraduate studies in several countries, in terms of validity and reliability, including the United Kingdom, Indonesia, Taiwan, and Malaysia.

All the previous researchers reviewed the evaluation of the English language exam agreed that the evaluation process should study the purpose of the English exam, meet the purposes that developed for, and analyze the skills that want to test. 


\section{Conclusions}

This paper is a unique study that focuses on evaluating the National English Language Exam (NELE) in Jordan for postgraduate studies in terms of validity and reliability, and this paper concludes the following issues:

$\checkmark$ There is no study evaluating the National English Language Exam (NELE) in Jordan for postgraduate studies, especially in terms of validity and reliability.

$\checkmark$ Seven steps to effectively evaluate the validity and reliability of the NELE in Jordan for postgraduate studies must be followed.

$\checkmark$ Designing and creating English language exams should be conducted incorporation with the specialists and the CAQA (Commission for Accreditation and Quality Assurance) to assure the validity and reliability of the skills exams in Jordan.

This paper recommended to conducting such studies to evaluate the validity and reliability of the National English Language Exam (NELE) in Jordan for postgraduate studies.

\section{References}

Akmar, A., \& Asiah, J. (2015). Toward an English Proficiency Test for Postgraduates in Malaysia. SAGE Open, 5(1), 1-10. https://doi.org/10.1177/2158244015597725

Al-Eiadeh, M., Al.Sobh, M., Al-Zoubi, S., \& Al-Khasawneh, F. (2016). Improving English Language Speaking Skills of Ajloun National University Students. International Journal of English and Education, 5(3), 181-195.

Alkhawaldeh, A. (2017). Graduate Students' Perceptions of the Impact of the Alternative National English Course on the Improvement of Their English Language Learning and Their Learning Challenges at the University of Jordan. Journal of Education and Practice, 8(15), 22-28.

Arabian Business Consultants for Development, (ABCD). (2017). The Jordan STEM Education Landscape A Report for the British Council, British Council Jordan. https://www.britishcouncil.jo/sites/default/files/stem_4.0.pdf.

Ball, D. L., \& Forzani, F. M. (2009). The Work of Teaching and the Challenge for Teacher Education. Journal of teacher education, 60(5), 497-511. https://doi.org/10.1177/0022487109348479

Bani-Khaled, T. (2013). Learning English in Difficult Circumstances: The Case of North Badiah Disadvantaged Schools in Jordan. Australian Journal of Basic and Applied Sciences, 7(8), 269-284.

Brown, H., \& Abeywickrama, P. (2010). Language assessment principles and classroom practices. In H. D. Brown and (2nd Ed), Nielsen Book Data, 355-373. Pearson: Pearson Education U.

Can, R. (2017). Analysis of Written Expression Revision Skills of the Students in Faculty of 
Education'. Educational Research and Reviews, 12(5), 267-271. https://doi.org/10.5897/ERR2016.3120

Coombe, C., \& Hubley, N. (2007). A practical guide to assessing English language learners. Michigan: The University of Michigan Press. https://doi.org/10.3998/mpub.170430

Davies, A. (1997). Demands of Being Professional in Language Testing. Language Testing, 14(3), 328-339. https://doi.org/10.1177/026553229701400309

Dwiniasih, D., \& Nugraha, A. (2019). Enhancing Students' Reading Comprehension Through Jigsaw. Academic Journal Perspective: Education, Language, and Literature, 7(1): 46-50. https://doi.org/10.33603/perspective.v7i1.1909

Educational Testing Service. (2008). Graduate Record Examinations, Educational Testing Service. In ETS, Factors that can influence performance on the GRE General Test 2006-2007, 1-105. New Jersey: Educational Testing Service (ETS).

El-Omari, A. (2016). Factors Affecting Students' Achievement in English Language Learning. Journal of Educational and Social Research, 6(2), 1-18. https://doi.org/10.5901/jesr.2016.v6n2p9

Embse, N., \& Hasson. (2012). Test anxiety and high-stakes test performance between school settings: implications for educators. Preventing School Failure, 56(2), 180-187. https://doi.org/10.1080/1045988X.2011.633285

Erfani, Shiva. (2014). An Investigation on the Attitudes of IELTS and TOEFL iBT Teachers: A Quantitative and Qualitative Washback Study. British Journal of Education, Society and Behavioural Science, 4(1), 88-102. https://doi.org/10.9734/BJESBS/2014/5674

Hardré, P. L., \& Hackett, S. (2015). Defining the Graduate College Experience: What it "should" versus “does" include. International Journal of Doctoral Studies, 10, 57-77. https://doi.org/10.28945/2102

Hashisho, N. H. (2009). An Investigation of the Status of English Language Instruction in the Lower Basic Stage in Jordanian Public Schools. Educational Sciences, 36(1), 179-191. http://journals.ju.edu.jo/DirasatEdu/article/viewFile/240/238

Herreid, C. F. (2006). Clicker Cases: Introducing Case Study Teaching into Large Classrooms. Journal of College Science Teaching, 36(2), 1-43.

Hughes, A. (2003). Testing for language teachers ( $2^{\text {nd }}$ ed.). Cambridge: Cambridge University Press. https://doi.org/10.1017/CBO9780511732980

IELTS Handbook. (2007). University of Cambridge web publication. Manchester: IELTS. https://vuonlen089.files.wordpress.com/2013/02/ielts-handbook-2007.pdf

Ali, Yasser. A., Daru, P., Al-Qaisi, Z., Rasim Ibrahim, M., Al-Mujafit, H., Al-Ees, A., \& ILO Regional Office for Arab States. (2015). Manual on skills testing and certification: Jordan. ILO. http://www.ilo.org/public/libdoc/ilo/2015/487661_ara.pdf 


\section{Macrothink}

KIRBY, J. R. (2007) Reading Comprehension: Its Nature and Development. In Encyclopedia of Language and Literacy Development. Canadian Language and Literacy Research Network, http://www.liter acyencyclopedia.ca/

Latitude Aviation English Services, (LAES). (2017). Checkpoint: language testing for students' selection: test reliability and validity. LAES, Bangalore. https://static1.squarespace.com/static/5742e4ef3c44d80a9c39295a/t/59115fa49de4bb22 db4e2fec/1494310827155/Checkpoint+-+Test+reliability+and+validity+-+May+2017.p df

Llurda, E. (2000). On Competence, Proficiency and Communicative Language Ability. International Journal of Applied Linguistics, 10(1), 85-95. https://doi.org/10.1111/j.1473-4192.2000.tb00141.x

Martins, F. S., Serra, F. R., \& Cunha, J. A. C. (2018). Editorial Comment: - Secondary Data in Research - Uses and Opportunities. Revista Ibero-Americana de Estratégia, 17(4), $1-4$.

http://www.spell.org.br/documentos/ver/48910/editorial-comment----secondary-data-in-r esearch-----uses-and-opportunities/i/en

Martirosyan, N.M., Hwang, E., \& Wanjohi, R. (2015). Impact of English proficiency on academic performance of international students. Journal of International Students, 5(1), 60-71.

https://www.researchgate.net/publication/306480671_Impact_of_English_Proficiency_o n_Academic_Performance_of_International_Students/citations

Ministry of Higher Education and Scientific Research, (MOHE), (2009a). Law No. (20) of 2009 and its Amendments Jordanian Universities Law. Amman: MOHE. http://www.mohe.gov.jo/en/GovPapers/the\%20jordanian\%20universities\%20law\%20no $\% 2020 . p d f$

Ministry of Higher Education and Scientific Research, (MOHE). (2009). Law No. (23), for the year 2009 Law of Higher Education and Scientific Research No. (23), for the year 2009.

Amman:

MOHE http://www.mohe.gov.jo/en/GovPapers/law\%20of\%20higher\%20education\%20and\%20s cientific\%20research\%201.pdf

Ministry of Higher Education and Scientific Research, (MOHE). (2019). National English Language Test: Test Competencies. Ministry of Higher Education and Scientific Research, Jordan university of science and technology, Irbid. http://www.just.edu.jo/FacultiesandDepartments/FacultyofGraduateStudies/Documents/ \%D8\%A7\%D9\%84\%D9\%83\%D9\%81\%D8\%A7\%D9\%8A\%D8\%A7\%D8\%AA\%20\% D8\%A7\%D9\%84\%D8\%A3\%D8\%B3\%D8\%A7\%D8\%B3\%D9\%8A\%D8\%A9\%20\%D9 \%84\%D9\%84\%D8\%A7\%D9\%85\%D8\%AA\%D8\%AD\%D8\%A7\%D9\%86\%20\%D8\% A7\%D9\%84\%D9\%88\%D8\%B7\%D9\%86\%D9\%8A\%20\%D9\%84\%D9\%84\%D8\%BA $\% \mathrm{D} 8 \% \mathrm{~A} 9 \% 20 \% \mathrm{D} 8 \% \mathrm{~A} 7 \% \mathrm{D} 9 \% 84 \% \mathrm{D} 8 \% \mathrm{~A} 5 \% \mathrm{D} 9 \% 86 \% \mathrm{D} 8 \% \mathrm{AC} \% \mathrm{D} 9 \% 84 \% \mathrm{D} 9 \% 8 \mathrm{~A} \%$ D8\%B2\%D9\%8A\%D8\%A9.pdf . 
Nour, S., \& Al-Wadi, M. (2015). The Jordanian Universities Competencies Tests Comparative Study. Conference Paper, IACQA 2015, 1-12. https://www.researchgate.net/publication/275154740_The_Jordanian_Universities_Com petencies_Tests_-_Comparative_Study.

Orbe, Ma. (2019). Investigating the Listening Comprehension Skills of Students: The Case of the Maritime Academy of Asia and the Pacific. Maritime academy of asia and the $\begin{array}{llll}\text { pacific kamaya } \quad \text { point, } & \text { 1-9. }\end{array}$ https://www.journals.aiac.org.au/index.php/IJALEL/article/view/1260

Oruç, N. (2015). Testing your Tests: Reliability Issues of Academic English Exams. International Journal of Psychology and Educational Studies, 2(2), 47-52. https://doi.org/10.17220/ijpes.2015.02.005

Rabab'ah, G. (2003). Communication Problems Facing Arab learners of English'. Language Learning Journal, $\quad 3(1), \quad 1740-4983$. https://www.researchgate.net/publication/228380118_Communication_problems_facing _Arab_learners_of_English

Roza, D., \& Kunci, K. (2019). The Challenges and Strategies in Teaching TOEFL and IELTS Test Preparation'. Journal of English for Academic, 6(2), 1-13. https://doi.org/10.25299/jshmic.2019.vol6(2).3067

Salameh, W., \& Sathakathulla, A. (2012). 'The Impact of Social and Economic Factors on Students' English Language Performance in EFL Classrooms in Dubai Public Secondary Schools'. English Language and Literature Studies Archives, 8(4), 110-118. https://doi.org/10.5539/ells.v8n4p110

Shohamy, L., \& May, S. (2007). Language testing and assessment. Abingdon: Routledge.

Sims, J. (2015). A Valid and Reliable English Proficiency Exam: A Model from a University Language Program in Taiwan. English as a Global Language Education (EaGLE) Journal, 1(2), 91-125. https://doi.org/10.6294/EaGLE.2015.0102.04

Snell, J. (2014). Social Class and Language. In J. Snell, Handbook of Pragmatics (2 ${ }^{\text {nd }}$ edition). Amsterdam: John Benjamins.

Stephen, D., Welman, J., \& Jordaan, W. (2004). English Language Proficiency an Indicator of Academic Performance at a Tertiary Institution'. Journal of Human Resource Management, 2(3), 42-53. https://doi.org/10.4102/sajhrm.v2i3.48

Sugianto, A. (2016). An Analysis of English National Final Examination for Junior High School in Terms of Validity and Reliability. Journal on English as a Foreign Language, 6(3), 29-40. https://doi.org/10.23971/jefl.v6i1.427

Susanto, A. (2017). The Teaching of Vocabulary: a perspective. Journal kata, 1(2), 182-191. https://doi.org/10.22216/jk.v1i2.2136

Taguchi, N. (2014). English-Medium Education in the Global Society'. IRAL, 52(2), 89-98. 
https://doi.org/10.1515/iral-2014-0004

The Education, Audiovisual and Culture Executive Agency, (EACEA). (2017). Overview of the Higher Education System. Brussel: EACEA. https://eacea.ec.europa.eu/sites/eacea-site/files/countryfiches_armenia_2017.pdf

The Glossary of Education Reform. (2014). High-Stakes Test. https://www.edglossary.org/high-stakes-testing/

Weir, Cyril. (2005). Language testing and validation: An Evidence based approach. London: Palgrave Macmillan.

\section{Copyright Disclaimer}

Copyright for this article is retained by the author(s), with first publication rights granted to the journal.

This is an open-access article distributed under the terms and conditions of the Creative Commons Attribution license (http://creativecommons.org/licenses/by/4.0/). 